\title{
Nilai-Nilai Pendidikan Sosial dalam Al-Qur'an Surat Ali Imran Ayat 134 (Analisis Tafsir Al- Qur'an Al-Azhim Karya Ibnu Katsir)
}

\author{
Abdul Aziz Zaenal Muttaqin \\ Institut Agama Islam Darussalam (IAID), Ciamis-Jawa Barat \\ Email: aazm2017@gmail.com \\ Fadlil Yani Ainusyamsi \\ Universitas Islam Negeri (UIN) Sunan Gunung Djati Bandung \\ Pepe Iswanto \\ Institut Agama Islam Darussalam (IAID), Ciamis-Jawa Barat
}

\begin{abstract}
This study aims to determine: (1) the content of the al-Qur'an surah Ali Imran verse $134 ;$ (2) the values of social education contained in al-Qur'an surah Ali Imran verse 134 according to Ibn Katsir's Tafsir al-Qur'an alAzhim; (3) the relevance of the value of education in al-Qur'an surah Ali Imran verse 134 with today's education. This study uses the Maudhu'iy (thematic) method, namely the method of interpreting the verses of the Qur'an according to a particular theme or topic. Meanwhile, the data collection technique used in this research is literature study or documentation. The data analysis technique used in this study is the Moleong data analysis technique, which includes the stages of data reduction, data display, drawing conclusions and verification. After analyzing the data, the authors obtained the following conclusions: first, the contents of the al-Qur'an Surah Ali Imran verse 134 describes the characteristics of a pious person. Secondly, Ibn Kathir also said that the al-Qur'an surah Ali Imran verse 134 describes the characteristics of a pious person, including 1) Berinfaq in a field or narrow, happy or difficult. 2) Hold back anger when able to vent it. 3) Forgive those who wrong us even without being asked. 4) Do well. Apart from being the characteristics of a pious person, these four characteristics are also included in the values of social education, where these traits cannot be realized without social interaction with other people. third, the values of social education contained in al-Qur'an surah Ali Imran verse 134 when connected with contemporary education are very relevant, given the importance of these values to be possessed by educators and students and society in general.
\end{abstract}

Keywords: Values, Education, Social Education 


\section{PENDAHULUAN}

Kitab suci al-Qur'an diyakini kaum muslimin sebagai mukjizat utama Rasul terakhir Muhammad Saw. Bacaan mulia ini, sebagaimana ditulis oleh M. Quraish Shihab, berfungsi utama sebagai petunjuk (hudan) untuk seluruh umat manusia. Petunjuk yang dimaksud adalah aturan-aturan pengelolaan kehidupan di dunia secara benar dan baik untuk menuju keselamatan dan kebahagiaan kehidupan akhirat. Petunjuk-petunjuk agama ini akrab kita kenal dengan istilah "syari'at". Termuat di dalam kaidah-kaidah hukum, prinsip iman (akidah), kaidah akhlak (etika), kabar gembira, dan ancaman serta peringatan-peringatan kepada seluruh manusia (Monib \& Bahrawi, 2011: 109).

Pada dasarnya manusia diciptakan dengan kecenderungan untuk berinteraksi, bermasyarakat dan saling menolong dalam memenuhi kebutuhan hidupnya. Kebutuhan dasar ini disebut naluri (gregariousness). Manusia merupakan makhluk yang memiliki peran dalam kehidupan, baik sebagai makhluk sosial maupun ekonomi. Secara alami, manusia akan berusaha memenuhi keinginannya tersebut. Dalam memenuhi keinginannya, manusia senantiasa berhubungan atau berinteraksi dengan orang lain dan memperhatikan keterbatasan sumber daya, artinya manusia bertindak sebagai makhluk sosial dan juga ekonomi.

Manusia dalam menghadapi kehidupannya tidak dapat memenuhi kebutuhan hidupnya seorang diri karena setiap manusia akan bergantung kepada manusia lain. Hal ini yang menyebutkan bahwa manusia adalah makhluk sosial (homo socialis). Sebagai makhluk sosial manusia melakukan berbagai kegiatan, berinteraksi dengan sesama manusia dan lingkungannya. Hal ini dilakukan untuk mempertahankan hidupnnya dan berkembang. Menurut Aristoteles, manusia adalah zoon politicon yang berarti manusia dikodratkan untuk hidup bermasyarakat. Adapun faktor yang mendorong manusia untuk hidup bermasyarakat yaitu faktor sosial, faktor perkawinan, faktor senasib dan faktor untuk bersatu sehingga manusia akan berusaha untuk memenuhi kebutuhan hidupnya, termasuk kebutuhan sosialnya (Huda \& Dkk, 2017: 177).

Salah satu implementasi dari manusia sebagai makhluk sosial adalah adanya hidup bertetangga. Hidup bertetangga merupakan bagian dari fitrah manusia dan sunnatullah. Sebagai fitrah, karena dalam diri manusia, sebagai makhluk sosial mempunyai kecenderungan untuk berteman, berkelompok-kelompok dan tinggal bersama di suatu tempat atau daerah. Hal ini merupakan sunnatullah sebagaimana dijelaskan dalam firman Allah Swt. "Hai manusia sesungguhnya Kami menciptakan kamu dari seorang laki-laki dan seorang perempuan dan menjadikan kamu berbangsa-bangsa dan bersuku-suku supaya kamu saling kenalmengenal.....(Q.S. Al Hujurat, 49:13) 


\section{BESTARI}

Vol. 17, No. 1, 2020

p-ISSN 1907-1337; e-ISSN 2807-6532

Namun dalam hidup bertetangga ada hak dan kewajibannya. Hak dan kewajiban bertetangga sama antara orang yang satu dengan yang lainnya. Hanya yang membedakannya adalah dalam hal-hal yang bersifat khusus. Dalam hidup bermasyarakat semuanya mempunyai hak yang sama, kecuali dalam aktivitas keimanan, beribadah dan beragama saja yang berbeda dan berlainan. Hak-hak orang yang satu agama dalam bertetangga tak bisa disamakan dengan mereka yang berlainan agama, terkecuali dalam hal aktivitas sosial kemasyarakatan (Muhsin, 2004: 1011). Soal perbedaan ini Allah Swt. berfirman, "Perbandingan dua golongan itu (orang-orang kafir dan orang-orang mukmin), seperti orang buta dan tuli dan orang yang dapat melihat dan dapat mendengar. Apakah kedua golongan itu sama keadaan dan sifatnya?...(Q.S. Hud, 11:24)

Setiap bayi yang lahir dikaruniai potensi sosialitas. Pernyataan tersebut diartikan bahwa setiap anak dikaruniai benih kemungkinan untuk bergaul. Artinya, setiap orang dapat berkomunikasi yang pada hakikatnya di dalamnya terkandung unsur saling memberi dan menerima. Bahkan menurut Langeveld, adanya kesediaan untuk saling memberi dan menerima dipandang sebagai kunci sukses pergaulan (Tirtarahardja \& La Sulo, 2008: 18-19).

Rasulullah Muhammad Saw bersabda pada empat belas abad yang lalu, "Demi Allah, saya tidak takut dengan kemisikinan kalian, akan tetapi saya takut jika dunia menjadi lapang bagi kalian sebagaimana umat sebelum kalian sehingga mereka saling memperebutkannya.” Gejala inilah yang nampak ditengah masyarakat kita. Gotong royong lambat laun pupus oleh egoisme individu yang berkembang. Kejujuran hilang ditutupi dengan kebohongan. Persaudaraan sulit ditemukan kecuali di dalamnya terdapat uang. Kesombongan menggeser sifat lugu, sopan dan ketawadhu'an (Atmajaya, 2010: 61).

Allah Swt berfirman: "(yaitu) orang-orang yang menafkahkan (hartanya), baik di waktu lapang maupun sempit, dan orang-orang yang menahan amarahnya dan mema'afkan (kesalahan) orang. Allah menyukai orang-orang yang berbuat kebajikan.” (Q.S. Ali Imran, 3:134)

Dari uraian di atas, penulis akan mengkaji lebih dalam mengenai nilai-nilai pendidikan sosial apa saja yang terdapat dalam surat Ali Imran ayat 134 tersebut dengan mengangkat judul, yaitu: "Nilai-nilai Pendidikan Sosial dalam al-Qur'an Surat Ali Imran Ayat 134 (Analisis Tafsir alQur'an al-Azhim karya Ibnu Katsir)". 


\section{KAJIAN TEORI}

\section{Pendidikan Sosial}

Kata sosial kalau dirujuk asal usulnya, salah satunya dapat berakar dari kata latin, yaitu socius, yang berarti bersama-sama, bersatu, terikat, sekutu, berteman atau socio yang bermakna menyekutukan, menjadikan teman, mengikat atau mempertemukan. Dari pengertian dua kata tersebut, maka sosial dapat dipahami sebagai pertemanan atau masyarakat (Damsar \& Indrayani, 2016: 91).

Maksud dari pendidikan sosial dalam Ulwan (1981: 391) adalah pendidikan yang sejak kecil agar terbiasa mengerjakan dan menjalankan adab sosial yang baik dan dasar-dasar psikis yang mulia dan bersumber pada akidah Islamiyah yang abadi dan perasaan keimanan yang mendalam, agar di dalam masyarakat nanti ia bisa tampil dengan pergaulan dan adab yang baik, berkesinambungan yang matang dan tindakan yang bijaksana (Purwanti, 2016: 12).

Adapun pendapat para ahli pendidikan menafsirkan pendidikan sosial sebagai berikut:

Menurut Abdul Hamid al- Hasyimi Pendidikan sosial adalah bimbingan orang dewasa terhadap anak dengan memberikan pelatihan untuk pertumbuhan kehidupan sosial dan memberikan macam-macam pendidikan mengenai perilaku sosial dari sejak dini, agar hal itu mejadi elemen penting dalam pembentukan sosial yang sehat (Chami, 2006: 35).

Menurut St. Vembriarto pendidikan sosial adalah suatu usaha melalui proses untuk mempengaruhi dan mengembangkan sikap sosial pada anak dalam arti mengarahkan kegiatan (aktifitas) pada sosialisasi anak dalam lingkungan sosialnya (Chami, 2006: 35).

Menurut Nasikh Ulwan pendidikan sosial adalah mendidik manusia sejak kecil agar anak terbiasa menjalankan perilaku sosial yang baik, dan memiliki nilai dasar-dasar kejiwaan mulia bersumber pada aqidah dan keimanan yang mendalam, agar ditengah-tengah masyarakat nanti anak mampu bergaul dan berperilaku yang baik, mempunyai keseimbangan akal yang matang dan tindakan yang bijaksana (Chami, 2006: 35).

Jadi pendidikan sosial menurut beberapa pendapat di atas adalah suatu proses yang diusahakan oleh orang dewasa terhadap anak, secara sengaja dalam masyarakat untuk mendidik, membina, membangun individu dalam lingkungan sosial supaya ditengah-tengah masyarakat kelak anak mampu bergaul dan berperilaku yang baik terhadap sesama, tentunya selalu berpegang pada aqidah dan keimanan yang kokoh.

Rasulullah Saw memberikan contoh-contoh yang baik bagi kita dalam sebagian bidang yang bersifat sosial berikut ini:

a. Mengucapkan salam adalah ucapan selamat bagi Islam dan kunci bagi hubungan yang bersifat kemanusiaan. 


\section{BESTARI}

Vol. 17, No. 1, 2020

p-ISSN 1907-1337; e-ISSN 2807-6532

b. Pada suatu kali seorang budak perempuan di Madinah datang untuk mengambil dengan kekuasaan Rasulullah. Maka ia berangkat dengan beliau dan Rasulullah berjalan bersamanya dengan segala rasa simpati dan kasihan.

c. Bahwa Rasulullah Saw ditemani oleh Hasan atau Husain menuju masjid untuk hadir dalam shalat berjama'ah, sambil memperhatikan kondisi dan kehidupan sosial dengan apa yang mengelilinginya dari mainan-mainan anak-anak tersebut.

1) Pendekatan-Pendekatan Dalam Pendidikan Sosial

Pendekatan dalam pendidikan sosial dimaksudkan agar pelaksanaan pendidikan sosial dapat memenuhi sasaran dan harapan yang telah dicapai dan yang ditentukan, sehingga berhasil dapat bermanfaat bagi semua pihak.

Adapun pendekatan -pendekatan tersebut meliputi:

a) Pendekatan ditinjau dari segi sasarannya.

Dalam pendekatan ini, ditujukan pada apa yang terkena oleh pendekatan tersebut yakni manusia dan lingkungannya dimana progam pendidikan sosial ini meliputi serta akan dilaksanakan pada umumya.

Pendekatan ini meliputi:

(1) Pendekatan Mentalistik.

Pendekatan Mentalistik yaitu suatu usaha pendekatan terhadap anak didik dalam rangka mempengaruhi dan mengubah sikap dan tingkah lakunya dengan cara mempengaruhi dan mengubah sikap dan tingkah lakunya dengan cara mempengaruhi secara langsung mental anak didik yang bersangkutan. Pendekatan ini dapat di tempuh dengan beberapa tehnik antara lain: home visit yaitu (suatu metode dengan cara mendatangi rumah-rumah), ceramah yaitu (metode yang digunakan dengan cara menerangkan kepada anak didik), wawancara (metode dengan cara tanya jawab), penyuluhan (metode dengan cara memberikan pengetian yang sejelas-jelasnya) dan sebagainya.

\section{(2) Pendekatan Kondisional}

Pendekatan kondisional yaitu usaha pendekatan dengan cara mengubah kondisi dan situasi disekitar anak didik yang bersangkutan, yang mempunyai pengaruh langsung terhadap penghayatannya.

b) Pendekatan ditinjau dari segi pelaksanaannya.

Pendekatan ini dapat ditempuh dengan tiga cara yaitu:

(1) Cara Pendekatan Memaksa (force). 
Yaitu untuk pendidikan ini dilaksanakan dengan memaksa kehendaknya, rencananya kepada masyarakat dan masyarakat harus menerima apa yang telah ditentukan.

(2) Cara pendekatan menyesuaikan (persuasion).

Dalam cara ini dilaksanakan dengan menyediakan alat perlengkapan tertentu. Seperti film penerangan, siaran radio yang seluruhnya mengenai rencana-rencana dan cara-cara serta pelaksanaannya yang ditujukan kepada masyarakat.

(3) Cara pendekatan mendorong (stimulation).

Cara pendekatan ini ditempuh dengan jalan mendorong, merangsang masyarakat agar inisiatifnya timbul dan kemudian dengan sukarela melaksanakan program daerahnya dan untuk masyarakatnya.

Pendekatan-pendekatan menurut ST. Vembriarto dijelaskan dengan mencakup tiga macam aspek mental pribadi yaitu:

a) Pengetahuan

Maksud dari pengetahuan di sini adalah pengetahuan dalam arti yang seluas-luasnya, yaitu segala macam informasi yang diperoleh oleh seseorang dari berbagai macam sumber dari dunia sekitarnya. Keseluruhan pengetahuan dan penghayatan yang dialami oleh seseorang dalam perjalanan hidupnya, membentuk pengalaman orang itu. Pengetahuan dan pengalaman seseorang itu dapat mempengaruhi dan mengubah sikap orang itu terhadap sesuatu obyek. Perubahan sikap ini dapat mempengaruhi dan mengubah perbuatan orang tersebut. Pengetahuan yang dapat diberikan kepada anak didik dalam program pendidikan sosial memiliki valiabilita yang sangat luas sesuai dengan sasaran pendidikan sosial itu.

b) Sikap (attitude)

Sikap adalah kesediaan mental dan kecenderungan seseorang untuk bertindak terhadap sesuatu obyek. Obyek sikap ini dapat dibenda, manusia lain (perorangan atau kelompok) atau sesuatu yang abstrak (nilai, ideologi, faham sosial, dan sebagainya). Pendidikan merupakan usaha untuk mempengaruhi dan mengubah sikap anak didik dalam rangka mempengaruhi dan mengubah tingkah lakunya.

c) Perbuatan (keterampilan)

Pengertian keterampilan (skill) dalam arti sempit adalah kemudahan, kecepatan dan tingkah laku motorik yang disebut juga manusia skill dalam arti luas, ketrampilan meliputi aspek manual skill, intellectual skill, dan social skill. Jenis ketrampilan mana yang dititik beratkan dalam pendidikan sosial, hal itu tergantung pada programnya sesuai dengan sasaran pendidikannya. 


\section{BESTARI}

Vol. 17, No. 1, 2020

p-ISSN 1907-1337; e-ISSN 2807-6532

Aspek pengetahuan, sikap, dan keterampilan itu merupakan totalita dalam program-program pendidikan sosial. Ketiganya secara hakiki harus termuat dalam program, hanya saja mungkin titik beratnya berbeda-beda sesuai dengan prioritas program yang telah ditentukan (Chami, 2006: 41).

\section{2) Tujuan Pendidikan Sosial}

Suatu pendidikan tak terkecuali pendidikan sosial, tentu memiliki suatu tujuan, yaitu sesuatu yang diharapkan tercapai setelah usaha atau kegiatan selesai. Suatu tujuan yang hendak dicapai oleh pendidikan pada hakikatnya adalah suatu perwujudan dari nilai-nilai ideal yang terbentuk dalam pribadi manusia yang diinginkan. Nilai-nilai ideal itu mempengaruhi dan mewarnai pola kepribadian manusia, sehingga menggejala dalam perilaku lahiriyahnya. Dalam melaksanakan pendidikan sosial diharapkan akan tercapai sebuah tujuan yang dicitacitakan yaitu adanya manusia yang tanggap serta peduli terhadap masalah-masalah yang terjadi di lingkungan sekitarnya dan dengan adanya tujuan tersebut dapat membangkitkan semangat untuk berbuat sosial.

Sedangkan tujuan pendidikan menurut Omar at Toumy AsySyaibani ialah perubahan yang diinginkan dan diusahakan oleh proses dan usaha pendidikan untuk mencapainya, baik pada tingkah laku individu dan pada kehidupan pribadinya, kahidupan masyarakat dan alam sekitar di mana individu itu hidup, serta pada proses pendidikan itu sendiri dan proses pengajaran sebagai suatu aktivitas yang asasi dalam masyarakat (Munasifah, 2004).

Sedangkan tujuan umum pendidikan sosial dalam pandangan alSyaibani (1989: 410) merupakan tujuan yang berkaitan dengan pembinaan masyarakat Islam dengan mengembangkan aspek spiritual, kebudayaan, sosial, ekonomi dan politik (Sanusi \& Suryadi, 2018: 44).

3) Urgensi Pendidikan Sosial

Pentingnya pendidikan sosial ditanamkan di dalam masyarakat karena dalam kehidupan ini banyak terjadi hal-hal yang tidak sesuai dengan norma-norma yang berlaku. Pendidikan sosial ini melibatkan bimbingan terhadap tingkah laku sosial, ekonomi dan politik dalam rangka akidah Islam yang betul dan ajaran-ajaran dan hukum-hukum agama yang dapat meningkatkan iman, taqwa, takut kepada Allah dan mengerjakan ajaran-ajaran agama-Nya yang mendorong pada produksi, menghargai waktu, jujur, ikhlas dalam perbuatan, adil, kasih sayang, ikhsan, mementingkan orang lain, tolong menolong, setia kawan, menjaga kemaslahatan umum, cinta tanah air, dan lain-lain lagi bentuk akhlak yang mempunyai nilai sosial. Karena dengan pendidikan sosial orang akan memperhatikan dirinya sendiri dalam berbuat untuk orang 
lain, tidak akan semena-mena bila dalam keadaan berkecukupan karena sudah menerima pendidikan sosial (Munasifah, 2004: 20).

Adapun pentingnya pendidikan sosial menurut Al Ustadz Hasan Hafidz, dan kawan-kawan adalah:

a) Mempersiapkan anak agar dapat melakukan sesuatu yang berguna bagi masyarakat, yakni agar ia mempunyai kecakapan atau ketrampilan. Misalnya, masyarakat butuh akan tenaga guru, dokter, insinyur, pedagang, tukang kayu/ tukang batu dan lain-lain. Pendidikan di sini berarti memenuhi kebutuhan-kebutuhan masyarakat dari beberapa segi.

b) Mempersiapkan anak untuk mampu berkecimpung di tengahtengah masyarakat dengan mau menerima kenyataan yang ada, baik itu masyarakat kecil, keluarga, sekolah, teman sejawat atau masyarakat lainnya.

c) Membekali anak dengan ide-ide yang sehat (baik) dan kebiasaan-kebiasaan yang mulia untuk dapat hidup di masyarakat serta meningkatkan kemampuannya berinteraksi sosial sehingga menjadi teladan bagi masyarakatnya, berakhlak mulia, menjaga keluarga, berpegang teguh pada tingkah laku yang baik, berdisiplin, tolong menolong, mendahulukan kepentingan umum, bertanggungjawab, menjunjung tinggi norma-norma dan undang-undang yang berlaku.

d) Memberikan pengertian pada anak tentang hak-hak dan kewajiban-kewajiban yang harus dijaga dan dilaksanakan.

e) Meningkatkan kehidupan bernegara dan membina generasi penerus yang bertanggungjawab dan mempunyai nasionalisme yang tinggi dengan membekali budaya bangsa, menjunjung tinggi cita-cita luhur bangsa dan negaranya, menanamkan dan menumbuh suburkan rasa harga diri, jiwa bebas dan merdeka.

f) Mengenalkan pada anak tentang problem-problem ekonomi, sosial dan kesehatan masyarakat sekitar serta menanamkan kecenderungan, kemauan dan kemampuan untuk memecahkan problemproblem tersebut secara baik dan efisien.

g) Mempelajari situasi dan kondisi masyarakat, menunjukkan kebaikan-kebaikannya dan bagaimana cara melestarikannya. Disamping itu juga kejelekan kekurangan-kekurangannya dan bagaimana mengatasinya, mengikuti perubahan-perubahan sosial dan mengadakan pengabdian masyarakat demi perbaikan dan peningkatan tarap hidup kehidupan masyarakat.

Dari paparan uraian tersebut di atas, pendidikan sosial menjadi sangat penting dan diperlukan dalam membangun masyarakat yang sadar akan lingkungan sekitarnya. Melalui pendidikan sosial, diharapkan dapat mendidik dan membentuk manusia yang mengetahui dan menginsyafi 


\section{BESTARI}

Vol. 17, No. 1, 2020

p-ISSN 1907-1337; e-ISSN 2807-6532

tugas dan kewajibannya terhadap berbagai golongan masyarakat dan membiasakannya berperilaku sosial yang baik sebagai anggota masyarakat, dan sebagai warga negara mengetahui dan menginsyafi tugas dan kewajibannya untuk dilaksanakan terhadap anggota masyarakat yang lain merupakan ciri utama dari suatu pendidikan sosial. Dengan melihat betapa pentingnya pendidikan sosial, maka kita harus mendidik anak secara baik dan mempersiapkannya untuk dapat hidup di masyarakat dan mengarahkan kepribadiannya untuk berkehidupan sosial yang baik, serta meningkatkan kepedulian kita terhadap sesama agar mereka tidak merasa hina karena adanya perbedaan ekonomi (Munasifah, 2004).

\section{Nilai Pendidikan Sosial}

Nilai Pendidikan sosial adalah suatu usaha manusia untuk membina kepribadiannya sesuai dengan nilai-nilai dan kebudayaan yang dianggap baik yang selalu diinginkan, dicita-citakan dan dianggap penting oleh seluruh manusia sebagai anggota masyarakat. Dengan demikian dapat dikatakan bahwa nilai pendidikan sosial adalah suatu hikmah yang dapat diambil dan menjadikan pembelajaran dari suatu tindakan atau kebudayaan yang ada dalam masyarakat atau nilai-nilai sosial yang terdapat di dalam masyarakat (Fadhilah, 2016: 7-8).

\section{METODE}

Jenis penelitian ini adalah penelitian perpustakaan (library research), yaitu penelitian yang dilakukan dengan cara mengadakan studi atau penelaahan terhadap buku-buku atau literatur yang berkaitan dengan pokok permasalahan yang dibahas (Muallifah, 2008: 23-24).

Penelitian ini menggunakan metode Maudhu'iy (tematik), yaitu metode penafsiran ayat-ayat al-qur'an menurut tema atau topik tertentu. Tafsir metode tematik ini memiliki dua bentuk. Pertama, penafsiran menyangkut satu surat dalam al-Qur'an secara menyeluruh dan utuh, dengan menjelaskan tujuannya yang bersifat umum dan khusus, menjelaskan korelasi anatara persoalan-persoalan yang beragam dalam surat tersebut sehingga satu surat tersebut dengan berbagai masalahnya merupakan satu kesatuan yang utuh (Supiana, 2017: 157). Kedua, penafsiran yang bermula dari menghimpun ayat-ayat al-Qur'an yang membahas satu masalah tertentu dari berbagai ayat dan surat al-Qur'an yang diurut sesuai dengan urutan nuzulnya, kemudian menjelaskan pengertian menyeluruh dari ayat-ayat tersebut untuk menarik petunjuk al-Qur'an secara utuh tentang masalah yang dibahas (Supiana, 2017: 158).

Sumber primer merupakan buku utama yang dijadikan sebagai bahan analisis dalam penelitian ini. Dan sumber primer yang digunakan dalam penelitian ini adalah berupa buku Tafsir al-Qur'an al-Azhim karya Ibnu Katsir, terutama Tafsir al-Qur’an al-Azhim Jilid 1. 
Sumber sekunder, yaitu berupa sumber pendukung sumber primer sebagai bahan untuk menyusun penelitian ini. Sumber sekunder berasal dari buku, jurnal, artikel serta karya tulis lain yang ada hubungannya dengan pembahasan penelitian. Adapun data sekunder yang dipakai adalah buku karangan Suharsimi Arikunto (Prosedur Penelitian), Ahmad Izzan (Metodologi Ilmu Tafsir), Uci Sanusi dan Rudi Ahmad Suryadi (Ilmu Pendidikan Islam), Darji Darmodiharjo dan Shidarta (Pokok-pokok Filsafat Hukum), Mohammad Monib dan Islah Bahrawi (Islam Dan Hak Asasi Manusia Dalam Pandangan Nurcholish Madjid), serta sumbersumber lain yang ada kaitannya dengan pembahasan ini.

Metode pengumpulan data dalam library research untuk memperoleh data dalam penulisan skripsi yaitu dengan cara riset kepustakaan atau penelitian murni. Penelitian ini bertujuan mencari dan mengumpulkan data dengan bantuan bermacam-macam alat atau materi yang terdapat didalam ruangan perpustakaan.

Selain itu, teknik pengumpulan data lainnya yang digunakan dalam penelitian ini yaitu menggunakan metode dokumentasi. Metode dokumentasi yang dimaksud dalam penelitian ini adalah mengumpulkan data-data berupa tulisan yang relevan dengan permasalahan fokus penelitian. Metode ini dilakukan dengan cara mencari dan menghimpun bahan-bahan pustaka berupa buku-buku, surat kabar, kitab-kitab tafsir, hadits-hadits dan lain sebagainya yang terkait dengan judul skripsi yang tujuannya itu untuk ditelaah isi tulisan terkait dengan judul skripsi (Sholihat, 2019: 53-54).

Teknik pengecekan keabsahan data merupakan cara-cara yang dilakukan peneliti untuk mengukur derajat kepercayaan (credibility) dalam proses pengumpulan dan penelitian. Trianggulasi data memanfaatkan sesuatu yang ada di luar data sebagai pembanding seperti: Membandingkan data dari metode yang sama dengan sumber yang berbeda dengan memanfaatkan teori lain untuk memeriksa data dengan tujuan penjelasan banding (Sholihat, 2019: 57).

Analisis data merupakan suatu upaya dalam menguraikan suatu masalah atau fokus kajian menjadi bagian-bagian sehingga susunan dan tatanan bentuk sesuatu yang diurai tersebut tampak dengan jelas terlihat dan mudah dicerna atau ditangkap maknanya (Helaluddin \& Wijaya, 2019: 99).

Manurut Patton dalam Moleong (2010: 280), teknik analisis data adalah proses kategori urutan data, mengorganisasikannya ke dalam suatu pola, kategori dan satuan uraian dasar. Ia membedakannya dengan penafsiran yaitu memberikan arti yang signifikan terhadap analisis, menjelaskan pola uraian dan mencari hubungan diantara dimensidimensi uraian. Sedangkan menurut Bogdan dan Tylor dalam Moleong (2010: 280), analisis data sebagai proses yang merinci usaha secara formal untuk menemukan tema dan merumuskan hipotesis seperti yang 


\section{BESTARI}

Vol. 17, No. 1, 2020

p-ISSN 1907-1337; e-ISSN 2807-6532

di saranakan oleh data dan sebagai usaha untuk memberikan bantuan pada tema dan hipotesis tersebut, jika dikaji definisi pertama lebih menitik beratkan pada pengorganisasian data sedangkan definisi yang kedua lebih menekankan maksud dan tujuan analisis data, dan dari kedua definisi tersebut dapat ditarik kesimpulan, analisis data, adalah proses mengorganisasikan dan mengurutkan data ke dalam pola, kategori dan satuan uraian dasar sehingga dapat ditemukan tema dan dapat dirumuskan hipotesis kerja seperti yang disarankan oleh data.

Dalam penelitian ini data dianalisis dengan cara berikut:

a. Reduksi Data

Reduksi data merupakan kegiatan merangkum catatan-catatan lapangan dengan memilah hal-hal yang pokok yang berhubungan dengan permasalahan penelitian, rangkuman catatan-catatan lapangan itu kemudian disusun secara sistematis agar memberikan gambaran yang lebih tajam serta mempermudah pelacakan kembali apabila sewaktuwaktu data diperlukan kembali. Peneliti menggunakan reduksi data dengan tujuan memudahkan dalam pengumpulan data di lapangan.

b. Display data

Display data berguna untuk melihat gambaran keseluruhan hasil penelitian, baik yang berbentuk matrik atau pengkodean, dari hasil reduksi data dan display data itulah selanjutnya peneliti dapat menarik kesimpulan data memverifikasikan sehingga menjadi kebermaknaan data. Peneliti menggunakan display data ini untuk melihat gambaran penelitian.

c. Kesimpulan dan Verifikasi

Untuk menetapkan kesimpulan yang lebih beralasan dan tidak lagi berbentuk kesimpulan yang coba-coba, maka verifikasi dilakukan sepanjang penelitian berlangsung sejalan dengan memberchek, trianggulasi dan audit trail, sehingga menjamin signifikansi atau kebermaknaan hasil penelitian. Peneliti menggunakan metode ini untuk memverifikasi kesimpulan yang jelas dan pasti.

\section{HASIL PENELITIAN DAN PEMBAHASAN}

\section{Kandungan al-Qur'an Surat Ali Imran Ayat 134}

Isi kandungan surat Ali Imran ayat 134 dalam al-Qur'an dan Tafsirnya Depertemen Agama RI (2011: 43-46) menjelaskan bahwa ayat ini langsung menjelaskan sifat-sifat orang yang bertakwa, yaitu: Pertama: Orang yang selalu menafkahkan hartanya baik dalam keadaan berkecukupan maupun dalam keadaan kesempitan (miskin), sesuai dengan kesanggupannya. Menafkahkan harta itu tidak diharuskan dalam 
jumlah yang ditentukan sehingga ada kesempatan bagi si miskin untuk memberi nafkah. Bersedekah boleh saja dengan barang atau uang yang sedikit nilainya, karena itulah apa yang dapat diberikan tetap akan memperoleh pahala dari Allah Swt. Kedua: Orang yang menahan amarahnya. Biasanya orang yang memperturutkan rasa amarahnya tidak dapat mengendalikan akal pikirannya dan ia akan melakukan tindakantindakan kejam dan jahat sehingga apabila dia sadar pasti menyesali tindakan yang dilakukannya itu dan dia akan merasa heran mengapa ia bertindak sejauh itu. Oleh karenanya bila seseorang dalam keadaan marah hendaklah ia berusaha sekuat tenaga menahan rasa amarahnya lebih dahulu. Apabila ia telah menguasai dirinya kembali dan amarahnya sudah mulai reda, barulah ia melakukan tindakan yang adil sebagai balasan atas perlakuan orang terhadap dirinya. Ketiga: Orang yang memaafkan kesalahan orang lain. Memaafkan kesalahan orang lain sedang kita sanggup membalasnya dengan balasan yang setimpal, adalah suatu sifat yang baik yang harus dimiliki oleh setiap Muslim. Mungkin hal ini sulit dipraktekkan karena sudah menjadi kebiasaan bagi manusia membalas kejahatan dengan kejahatan tetapi bagi manusia yang sudah tinggi akhlak dan kuat imannya serta telah dipenuhi jiwanya dengan ketakwaan, maka memaafkan kesalahan itu mudah saja baginya. Keempat: Orang yang berbuat baik. Berbuat baik termasuk sifat orang yang bertakwa maka di samping memaafkan kesalahan orang lain hendaklah memaafkan itu diiringi dengan berbuat baik kepada orang yang melakukan kesalahan.

2. Nilai-Nilai Pendidikan Sosial dalam al-Qur'an Surat Ali Imran Ayat 134 Menurut Tafsir al-Qur'an al-Azhim karya Ibnu Katsir

Dalam al-Qur'an surat Ali Imran ayat 134 terkait dengan pendidikan sosial adalah berinfak, menahan marah, memaafkan orang lain dan berbuat kebaikan. Dalam pembahasan sebelumnya telah dijelaskan, bahwa ada 4 sifat yang dimiliki oleh orang yang bertakwa berdasarkan al-Qur'an surat Ali Imran ayat 134. Tentu orang yang masuk surga bukanlah orang baik hanya dalam hubungan dengan Allah (hablumminallah) saja, tetapi baik juga hubungannya dengan sesama manusia (hablumminannas) dalam kehidupan sosial masyarakat.

a. Berinfaq

Infaq berasal dari pecahan kata "Anfaqa, yunfiqu, infaq" yang artinya membelanjakan. Maksud arti membelanjakan sebagian harta yang ia miliki untuk kepentingan dijalan Allah (fisabilillah). kalimat:

Ibnu Katsir menjelaskan dalam Kitab Tafsir al-Qur'an al-Azhim الَّذِينَ يُنْفِقُونَ فِي السََّّاءِ وَالضََّاَّاءِ 


\section{BESTARI}

Vol. 17, No. 1, 2020

p-ISSN 1907-1337; e-ISSN 2807-6532

(yaitu) orang-orang yang menafkahkan (hartanya) baik di waktu lapang maupun sempit. (Q.S. Ali Imran, 3:134)

Yakni bermakna dalam keadaan susah dan dalam keadaan makmur, dalam keadaan suka dan dalam keadaan duka, dalam keadaan sehat dan juga dalam keadaan sakit. Dengan kata lain, mereka rajin berinfak dalam semua keadaan. Sebagaimana yang disebutkan dalam ayat yang lain, yaitu firman-Nya:

$$
\text { الَّذِينَ يُنْفِقُونَ أمْوالَهُمْ باللَّيْلْ وَالنَّهار سِِرَّا وَعَلانِيَةً }
$$

Orang-orang yang menafkahkan hartanya di malam dan di siang hari secara sembunyi dan terang-terangan. (Q.S. Al-Baqarah, 2: 274)

Makna yang dimaksud ialah bahwa mereka tidak kendur dan lupa oleh suatu urusan pun dalam menjalankan ketaatan kepada Allah Swt. Mereka membelanjakan harta untuk keridaan-Nya serta berbuat baik kepada sesamanya dari kalangan kaum kerabatnya dan orang-orang lain dengan berbagai macam kebajikan.

Menurut al-Qur'an menginfakkan harta secara baik dan benar termasuk salah satu ukuran dan indikasi sifat ketaqwaan manusia kepada Allah Swt, seperti disebut dalam surat Al-Baqarah ayat 2-3: "Kitab (alQur'an) ini tidak ada keraguan didalamnya, menjadi petunjuk bagi orangorang yang bertaqwa (2) (yaitu) mereka yang beriman kepada yang ghaib, mendirikan shalat, menafkahkan sebagian rezeki yang telah kami karuniakan kepada mereka (3).”

Orang yang telah menginfakkan hartanya secara baik berarti ia telah menanamkan investasi untuk dirinya sendiri. Oleh karena itu agama menganjurkan manusia agar menginfakkan hartanya secara terangterangan atau diam-diam, dan pada saat susah maupun senang. Dalam berinfak ini hendaknya diajuhi sifat riya', mengharapkan pujian orang lain atau motivasi keduniaan lainnya.

Pelaksanaan infaq yang diinginkan oleh agama ialah infaq yang dilakukan secara tulus ikhlas mengharapkan keridhan Allah. Dalam surat Al-Baqarah ayat 261 Allah berfirman: "Perumpamaan orang-orang yang menafkahkan pada jalan Allah adalah seumpama sebuah biji yang menumbuhkan tujuh tangkai, pada tiap-tiap tangkai berisi seratus biji dan Allah melipat gandakan bagi siapa yang dikehendaki-Nya, dan Allah Maha Luas (Karunia-Nya) lagi Maha Mengetahui."(Parmono \& Ismunandar, 2017).

b. Menahan Marah

Selanjutnya Ibnu Katsir menjelaskan potongan ayat berikutnya,

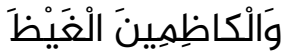


dan orang-orang yang menahan amarahnya. (Q.S. Ali Imran, 3:134)

Yakni mereka tidak melampiaskan kemarahannya kepada orang lain, melainkan mencegah dirinya agar tidak menyakiti orang lain, dan ia lakukan hal tersebut demi mengharapkan pahala Allah Swt.

Ibnu Katsir melanjutkan, apabila mereka mengalami emosi, maka mereka menahannya (yakni memendamnya dan tidak mengeluarkannya); selain itu mereka memaafkan orang-orang yang berbuat jahat kepada mereka.

Disebutkan dalam sebagian asar yang mengatakan:

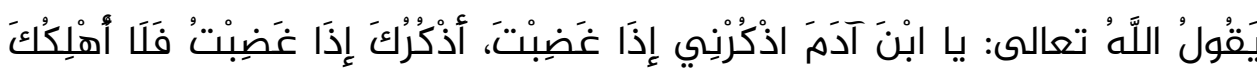
فِيمَنْ أهمِلِكُ

Allah Swt. berfirman, "Hai anak Adam, ingatlah kepada-Ku jika kamu marah, niscaya Aku mengingatmu bila Aku sedang murka kepadamu. Karena itu, Aku tidak akan membinasakanmu bersama orangorang yang Aku binasakan. (HR. Ibnu Abu Hatim)

Demikianlah menurut riwayat Ibnu Abu Hatim.

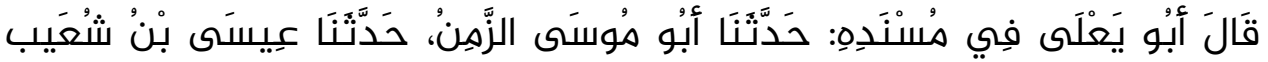

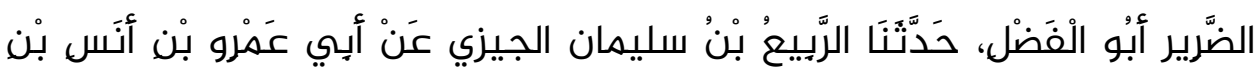

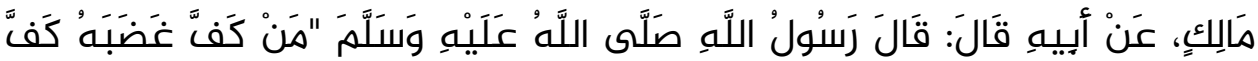

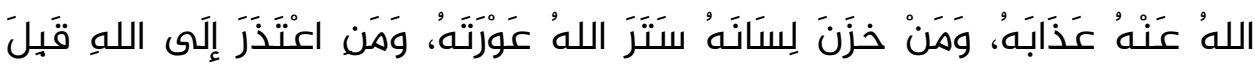
عُذْرَه"

Abu Ya'la mengatakan di dalam kitab musnadnya, telah menceritakan kepada kami Abu Musa Az-Zamin, telah menceritakan kepada kami Isa ibnu Syu'aib Ad-Darir (yaitu Abul Fadl), telah menceritakan kepadaku Ar-Rabi' ibnu Sulaiman, An-Numairi, dari Abu Amr ibnu Anas ibnu Malik, dari ayahnya yang mengatakan bahwa Rasulullah Saw. pernah bersabda: Barang siapa yang mengekang amarahnya, maka Allah menahan siksa-Nya terhadapnya. Dan barang siapa yang mengekang lisannya, maka Allah menutupi auratnya. Dan barang siapa yang meminta maaf kepada Allah, maka Allah menerima permintaan maafnya. (HR. Abu Ya'la)

Hadis ini garib, dan di dalam sanadnya terdapat hal yang masih perlu dipertimbangkan. 


\section{BESTARI}

Vol. 17, No. 1, 2020

p-ISSN 1907-1337; e-ISSN 2807-6532

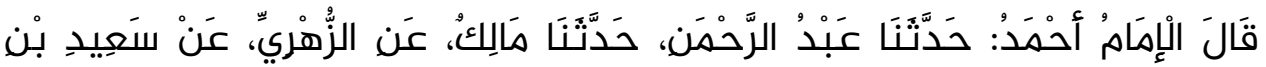

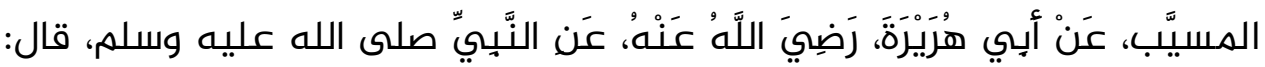

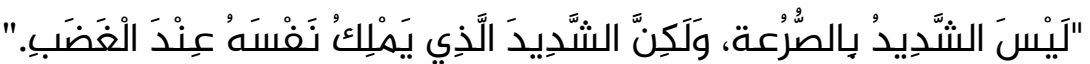

Imam Ahmad mengatakan, telah menceritakan kepada kami Abdur Rahman, telah menceritakan kepada kami Malik, dari Az-Zuhri, dari Sa'id ibnul Musayyab, dari Abu Hurairah r.a., dari Nabi Saw. yang telah bersabda: Orang yang kuat itu bukanlah karena jago gulat, tetapi orang kuat ialah orang yang dapat menahan dirinya di kala sedang marah. (HR. Bukhari, Muslim, dan Abu Daud).

Dari hadis tersebut jelas, bahwa standar orang kuat bukanlah dinilai dari tubuh yang kekar atau pandai bergulat. Akan tetapi orang yang kuat adalah orang yang mampu mengendalikan dirinya dan menahan marah ketika ia mampu melampiaskannya. Sebab jihad yang berat itu bukanlah melawan musuh-musuh Allah, tetapi jihad terberat adalah melawan hawa nafsu. Sebagaimana sabda Rasulullah Saw:

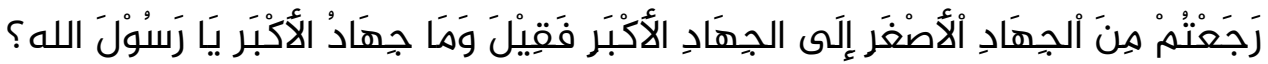

$$
\text { فَقَالَ جِهَادُ النَّفْسِ مِنَ }
$$

Kalian telah pulang dari sebuah pertempuran kecil menuju pertempuran besar. Lantas sahabat bertanya, "Apakah pertempuran akbar (yang lebih besar) itu wahai Rasulullah? Rasul menjawab, "jihad (memerangi) hawa nafsu." (HR. Al-Baihaqi)

Marah (ghadlab) merupakan fitrah yang telah diberikan Allah kepada setiap manusia. Setiap manusia pasti pernah merasakan marah. Namun, Islam telah memerintahkan umatnya agar bisa menahan amarah. Sebagaimana firman Allah Swt. ayat 134 .

Ayat ini menjelaskan bahwa mengendalikan amarah adalah salah satu sifat orang-orang yang bertakwa. Bahkan akan lebih utama lagi apabila ia memaafkan orang yang telah berbuat salah. Dalam sebuah hadis Qudsi disebutkan bahwa Nabi Musa as., pernah bertanya kepada Allah Swt., "Ya Rabbi! Siapakah diantara hamba-Mu yang lebih mulia menurut pandangan-Mu? Allah berfirman, "Orang yang ketika berhasil menguasai musuhnya dan memaafkannya."

Orang yang bisa bersabar/menahan amarah dan mampu memaafkan orang lain yang menyakitinya inilah orang yang kuat. Betapa tidak kuat, meski dia mampu membalas orang yang menyakitinya, akan tetapi semua itu tidak dilakukannya karena Allah semata. Atas dasar inilah, orang memiliki kemuliaan tinggi adalah orang yang mampu meamaafkan musuh-musuhnya. Sungguh, memaafkan orang-orang yang 
telah menyakiti dan memusuhi kita merupakan perkara yang sangat berat dan membutuhkan pengendalian emosi yang kuat.

Wajar saja apabila orang yang bisa memaafkan kesalahan orang lain dikategorikan oleh-Nya termasuk orang-orang bertakwa dan akan mendapatkan kemuliaan disisi Allah Swt. Allah berfirman, "Memaafkan itu lebih mendekatkan kepada takwa.”(Q.S. Al-Baqarah, 2: 237).

Dalam hadis-hadis sahih juga disebutkan mengenai keutamaan orang-orang yang mampu menahan amarahnya dan mau memaafkan orang lain. "Ada tiga hal yang apabila dilakukan akan dilindungi dalam peliharaan-Nya, ditaburi rahmat-Nya, dan dimasukkan ke dalam surga-Nya, yaitu apabila diberi ia berterima kasih ; apabila berkuasa ia suka memaafkan dan apabila marah ia menahan diri." (HR. Hakim dan Ibnu Hibban dari Ibnu 'Abbas) (El-Jambey 2016: 102).

Kemarahan bisa dipadamkan dengan cara berwudu. Air wudu akan mendinginkan kepala dan meredakan panas yang muncul dari luapan emosi. Akibatnya, dendam kesumat menjadi padam dan pikiran akan jernih kembali.

Dalam hadis yang lain disebutkan bahwa rasa marah bisa hilang dengan cara zikir kepada Allah Swt. Sebab dengan zikir hati seseorang akan menjadi tenang dan tentram. Kontrol diri semakin mantap dan hatinya selalu terpaut kepada Allah Swt. Tatkala hatinya selalu terpaut kepada Allah Swt., maka ia akan berpikir jernih dan sabar. Atas dasar itu, zikrullah adalah kendali dari rasa marah (El-Jambey 2016: 104).

c. Pemaaf

Pemaaf adalah sikap yang suka memberi maaf terhadap kesalahan orang lain tanpa ada sedikit pun rasa benci dan dendam di hati. Sifat pemaaf adalah salah satu manifestasi dari ketakwaan kepada Allah Swt. Jadi, takwa berarti membawa kita pada mulia (Syukur and Nahar 2014: 57).

Sebagaimana Allah Swt. berfirman:

$$
\text { وَالْعافِينَ عَنْ النَّاس }
$$

dan memaafkan (kesalahan) orang. (Q.S. Ali Imran, 3:134)

Ibnu Katsir menjelaskan maksud potongan ayat ini, yaitu selain menahan diri, tidak melampiaskan kemarahannya, mereka juga memaafkan orang yang telah berbuat aniaya terhadap dirinya, sehingga tiada suatu uneg-uneg pun yang ada dalam hati mereka terhadap seseorang. Hal ini merupakan akhlak yang paling sempurna.

Islam mengajarkan untuk bersikap pemaaf dan suka memaafkan kesalahan orang lain tanpa menunggu permohonan maaf dari orang yang berbuat salah kepada kita. Karenanya, tidak ditemukan satu ayat yang menganjurkan untuk meminta maaf, tetapi yang ada adalah perintah 


\section{BESTARI}

Vol. 17, No. 1, 2020

p-ISSN 1907-1337; e-ISSN 2807-6532

untuk memberi maaf (Syukur and Nahar 2014: 58).

Islam tidak pernah mengajarkan umatnya untuk bersifat pendendam. Rasulullah Saw menegaskan bahwa al-mukminu laisa bihaqd (orang beriman itu tidak punya sifat pendendam). Dengan kata lain, Islam tidak mengenal ungkapan "Tiada maaf bagimu". Oleh karena itu, sebagai seorang muslim kita harus menghilangkan segala sifat dendam dan menebarkan sifat pemaaf.

Sebuah kisah yang cukup populer menceritakan kepada kita bagaimana sifat pemaaf Rasulullah Saw kepada musuhnya. Suatu hari, ketika beliau sedang istirahat seorang diri di sebatang pohon kurma, tibatiba datang seorang kafir yang hendak membunuhnya. Saat itu ia menghunuskan pedang kepada Nabi Saw. Dan berkata "Wahai Muhammad, siapa yang bisa melindungimu kalau hari ini kau kubunuh?” Dengan tenang Nabi Saw. menjawab, “Allah". Mendengar jawaban spontan dari Rasulullah, tubuh si kafir tadi bergetar dan akhirnya terjatuhlah pedangnya ke tanah. Kemudian Nabi memungut pedang tersebut dan menanyakan hal yang sama kepada kafir tersebut. Ia ketakutan dan menyatakan hanya Rasulullah saja yang dapat melindungi dirinya dari kematian. Nabi pun memaafkannya. Tidak sedikit pun tergores rasa dendam beliau kepada orang tersebut (Iqbal 2005: 104-105).

Dalam tafsir Ibnu Katsir disebutkan sebuah hadis bahwa nabi bersumpah kepada tiga hal, bahwa tidak akan berkurang kemuliaan seorang karena memberi maaf, dan derajat orang-orang yang tawadhu' akan diangkat oleh Allah. Tidak akan rendah atau hina manusia yang gampang memaafkan, hanya kemuliaan demi kemuliaan yang ia peroleh.

Bukan hanya di dunia ini tetapi diakhirat kelak para pemaaf diseru dengan panggilan penuh kemuliaan di hadapan seluruh manusia, diajak mendekat kepada Tuhannya lalu dipersilakan mengambil pahala kebaiakannya, kemudian surga yang penuh kenikmatan sudah menanti kedatangannya (Syahrul 2016: 128-129).

d. Berbuat Baik

Sebagaimana firman Allah dalam akhir ayat surat Ali Imran ayat 134 disebutkan:

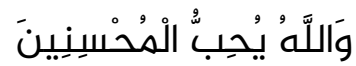

Allah menyukai orang-orang yang berbuat kebajikan. (Q.S. Ali Imran, 3:134)

Berbuat baik atau sering kita kenal juga dengan sebutan ihsan. Lubis (2019: 105) mengatakan ihsan menurut bahasa berarti kebaikan yang memiliki dua sasaran. Pertama, ia memberikan berbagai kenikmatan atau manfaat kepada orang lain. Kedua, ia memperbaiki 
tingkah laku berdasarkan apa yang diketahuinya yang manfaatnya kembali kepada diri sendiri. al-Qur'an menekankan agar manusia tidak hanya berbuat ihsan kepada Allah, tetapi juga berbuat ihsan kepada seluruh makhluk Allah, yakni manusia dan alam, termasuk hewan dan tumbuhan. Ihsan kepada Allah merupakan modal yang sangat berharga untuk berbuat ihsan kepada sesama. al-Qur'an memberi penghargaan yang tinggi terhadap perbuatan ihsan yang dilakukan manusia terhadap sesama dan lingkungan hidupnya seperti tersirat pada ayat-ayat al-Qur'an berikut ini: (1) tidak ada balasan bagi perbuatan ihsan kecuali ihsan yang lebih sempurna (Q.S. Ar-Rahman, 55: 60); (2) perbuatan ihsan itu kembali kepada dirinya sendiri (Q.S. Al-Isra, 17: 7); (3) perbuatan ihsan itu tidak akan pernah sia-sia (Q.S. Hud, 11:115); (4) kasih sayang Allah diberikan dengan mudah dan cepat kepada orang-orang yang terbiasa berbuat ihsan (QS. Al-Araf, 7: 56).

Di dalam sebuah hadis disebutkan seperti berikut:

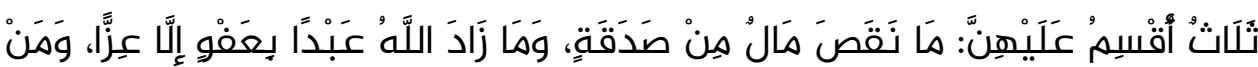

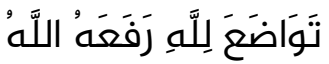

Ada tiga perkara yang aku berani bersumpah untuknya; tiada harta yang berkurang karena sedekah, dan tidak sekali-kali Allah menambahkan kepada seorang hamba yang pemaaf melainkan hanya keagungan; serta barang siapa yang merendahkan dirinya karena Allah, niscaya Allah mengangkat (kedudukan)nya. (HR. Tirmidzi)

Dalam hadis tersebut dijelaskan beberapa amal yang baik atau kebaikan, diantaranya adalah sedekah, menjadi orang yang pemaaf dan merendahkan diri kepada Allah. Kemudian Allah telah menjanjikan bagi siapa saja yang mengerjakan amal baik tersebut, maka Allah akan memberikan balasan sesuai dengan amal yang dikerjakannya. Sebab sekecil apa pun amalan yang dikerjakan seorang hamba, maka kelak dia akan mendapatkan balasannya. Sebagaimana firman Allah Swt:

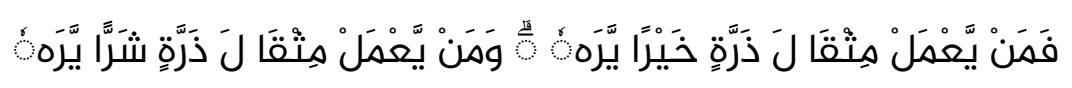

Maka barang siapa mengerjakan kebaikan seberat zarrah, niscaya dia akan melihat (balasan)nya. (7) Dan barang siapa mengerjakan kejahatan seberat zarrah, niscaya dia akan melihat (balasan)nya (8) . (Q.S. Az-Zalzalah,99:7-8)

Allah mewajibkan ihsan dalam segala perbuatan, baik yang batin maupun yang lahir (jawarih) yang dihadapkan kepada Allah. Maksudnya, lingkup ihsan meliputi ikhlas, kebaikan dan kesempurnaan pekerjaan itu.

Nabi Saw bersabda:

"Sesungguhnya Allah mewajibkan Ihsan (kebaikan) atas segala sesuatu." 


\section{BESTARI}

Vol. 17, No. 1, 2020

p-ISSN 1907-1337; e-ISSN 2807-6532

Allah menuntut kita untuk berbuat ihsan, yakni berbuat baik dalam melaksanakan amalan yang disyariatkan. Kita dituntut untuk berbuat baik kepada semua orang, baik kepada diri sendiri, keluarga, pelayan, manusia secara umum, bahkan kepada para Nabi, ulama, malaikat, jin, hewan, langit, bumi, dan tumbuhan.

Berbuat baik kepada diri sendiri adalah dengan mengarahkan hati dan anggota tubuh kepada ketaatan dan menghindari apa-apa yang dilarang. Tidak menempatkan diri pada posisi yang tidak baik. Tidak menzalimi diri sendiri dengan cara berbuat maksiat. Tidak meuruti segala keinginan hawa nafsu, dan tidak pula melampiaskan amarah.

Berbuat baik kepada keluarga dan pelayan dapat dilakukan dengan bergaul bersama mereka dengan baik, lemah lembut, dan akhlak yang baik. Memerintahkan mereka berbuat kebaikan dan melarang mereka berbuat kemungkaran. Mengajarkan kepada mereka ilmu agama yang mereka butuhkan. Tidak membebani mereka dengan tugas yang tidak mampu dipikul. Tidak pula menelantarkan mereka. Nabi Saw bersabda:

"Cukup bagi seorang sebagai dosa dengan menelantarkan orang yang menjadi tanggungan." (HR Nasai).

Ihsan kepada manusia secara umum adalah dengan tidak menipu mereka, memberikan nasihat kepada mereka, bergaul dengan pergaulan yang baik bersama mereka, sabar menghadapi prilaku mereka yang mengganggu, memuliakan mereka, mengajarkan apa yang dapat bermanfaat bagi mereka, baik untuk kemaslahatan dunia atau akhirat. Menunjukkan kepada mereka jalan kebaikan dan menganjurkan untuk menjauhi kemungkaran. Berdo'a kepada Allah agar mereka mendapat hidayah dan taufiq. Bersedekah atas nama orang sudah mati diantara mereka, dan mendoakan orang-orang yang telah mendahului agar mendapat ampunan dan rahmat.

Ihsan kepada para Nabi adalah dengan mengimani keberadaan dan ajaran mereka yang datang dari Allah. Meyakini bahwa mereka adalah manusia pilihan Allah diantara para makhluknya.

Ihsan kepada ulama adalah dengan cara memuliakan mereka, dan tidak menyebarkan aib mereka.

Ihsan kepada malaikat adalah dengan mengimani keberadaan mereka, meyakini bahwa mereka adalah hamba-hamba yang dimuliakan Allah Swt.

Ihsan kepada jin adalah mendoakan kebaikan bagi mereka, tidak mengganggu mereka jika salah satu dari mereka tampak dihadapan kita.

Ihsan kepada binatang adalah dengan tidak membuat mereka kelaparan dan kehausan, tidak memukul mereka tanpa sebab, tidak membebani mereka dengan apa yang tidak sanggup mereka pikul. Ketika 
sedang berhenti, ada baiknya orang turun dari hewan tunggangannya terlebih dahulu untuk mengistirahatkannya kecuali jika ada keperluan. Ada hadis Nabi Saw tentang wanita yang diazab di neraka hanya karena seekor kucing. Ia mengikatnya, tidak memberikan makan dan minum kepadanya, dan tidak pula melepaskannya agar ia bisa mencari makan sendiri sampai akhirnya kucing mati itu sendiri.

Ihsan kepada langit dan bumi adalah dengan merenungkan penciptaan keduanya dan kewajiban-kewajiban yang ada padanya. Menjaga kelestarian alam dan tidak berbuat maksiat, sebab dengan meninggalkan maksiat seseorang telah membuat langit dan bumi senang karena terlepas dari kewajiban bersaksi kelak di hari kiamat.

Ihsan kepada tumbuhan adalah dengan merawat, memberi air, dan menjaganya dari hal-hal yang dapat merusak (Hasan 2018: 57-61).

\section{Relevansi Nilai Pendidikan Sosial dalam al-Qur'an Surat Ali Imran Ayat 134 dengan Pendidikan Masa Kini}

Pendidikan sosial menjadi sangat penting dan diperlukan dalam rangka membangun masyarakat yang sadar akan lingkungan sekitarnya. Melalui pendidikan sosial, diharapkan dapat mendidik dan membentuk manusia yang mengetahui dan menginsyafi tugas dan kewajibannya terhadap berbagai golongan masyarakat dan membiasakannya berperilaku sosial yang baik sebagai anggota masyarakat, dan sebagai warga negara mengetahui dan menginsyafi tugas dan kewajibannya untuk dilaksanakan terhadap anggota masyarakat yang lain merupakan ciri utama dari suatu pendidikan sosial.

Sebagaimana telah dijelaskan di bab sebelumnya. M.J. Langeveld menyebutkan bahwa tujuan pendidikan merupakan upaya dalam membimbing manusia yang belum dewasa kearah kedewasaan. Pendidikan adalah suatu usaha dalam menolong anak untuk melakuakan tugas-tugas hidupnya, agar mandiri dan bertanggung jawab secara susila. Pendidikan juga diartikan sebagai usaha untuk menacapai penentuan diri dan tanggung jawab (Darmadi 2019: 16).

Sedangkan tujuan umum pendidikan sosial dalam pandangan alSyaibani (1989: 410) merupakan tujuan yang berkaitan dengan pembinaan masyarakat Islam dengan mengembangkan aspek spiritual, kebudayaan, sosial, ekonomi dan politik (Sanusi \& Suryadi, 2018: 44).

Berdasarkan penafsiran al-Qur'an surat Ali Imran ayat 134 jika dihubungkan dengan pendidikan masa kini, maka hendaknya seorang pendidik harus memberikan teladan kepada peserta didik berkaiatan dengan sifat-sifat orang yang bertakwa yang telah disebutkan dalam surat Ali Imran ayat 134, dengan cara memberikan pemahaman kepada peserta didik tentang pentingnya dan keutamaan memiliki sifat-sifat tersebut, serta yang terpenting adalah implementasi dari sifat-sifat tersebut harus dimulai dari pribadi pendidik itu sendiri. Artinya pendidik bukan hanya 


\section{BESTARI}

Vol. 17, No. 1, 2020

p-ISSN 1907-1337; e-ISSN 2807-6532

menyuruh atau memerintah saja, akan tetapi sudah melaksanakan dan menerapkan terlebih dahulu sifat-sifat tersebut sedikit demi sedikit.

Nilai pendidikan sosial yang terdapat dalam al-Qur'an surat Ali Imran ayat 134 jika dikaitkan dengan pendidikan masa kini sangatlah relevan dan sesuai apabila sifat tersebut dimiliki oleh pendidik maupun peserta didik. Semua sifat tersebut apabila dipandang dari sudut pandang sosial masyarakat, termasuk sifat yang baik dan sesuai dengan normanorma yang berlaku dalam kehidupan bermasyarakat.

Berinfaq merupakan salah satu bentuk kepedulian seseorang terhadap orang lain, terutama orang yang sangat membutuhkan. Jika melihat fakta pendidikan dimasa kini, kita bisa melihat bahwa ada sebagian lembaga pendidikan yang membiasakan peserta didiknya untuk berinfaq.

Salah satu contoh lembaga yang membiasakan siswanya berinfak sebagaimana yang dikutip dari Pikiran Rakyat.com, bahwa SD Assalam Bandung Jln. Sasak gantung mengadakan program sehari Rp 1.000,per siswa untuk membiasakan siswa berinfak. Hasil pengumpulan uang itu untuk bakti sosial kepada panti asuhan yatim dan piatu serta korban banjir di Kab. Bandung.

Seorang guru harus menunjukkan sifat pemaaf kepada siswa yang membuat pelanggaran baik sengaja maupun tidak sengaja. Begitulah akhlak pendidikan yang baik dan dihargai sepanjang masa sebagaimana sifat pemaaf Rasulullah kepada musuh yang menyiksa beliau dan membunuh para sahabatnya. Bayangkan betapa beratnya tantangan Rasul terhadap musuhnya, namun dapat dimaafkan (Hasan 2018: 102).

Begitupun siswa dengan siswa yang lainnya harus memiliki sikap pemaaf ketika ada salah seorang siswa melakukan kesalahan. Jangan sampai tumbuh dalam hati perasaan dendam bahkan sampai melakukan tindakan yang mengarah pada kontak fisik.

Selanjutnya, seorang guru juga harus bisa menahan amarahnya, karena dalam kegiatan belajar mengajar sedikit banyaknya pasti ada saja perilaku dari siswa-siswa yang membuat guru marah . Oleh sebab itu, sifat ini sangat penting dan harus dimiliki oleh setiap guru sehingga tidak akan terjadi hal-hal akibat dari marah itu yang tidak sesuai dengan keharusan seorang guru, seperti mengeluarkan kata-kata kasar, kata-kata kotor, bahkan sampai terjadi penganiayaan terhadap siswa yang banyak diberitakan di media-media. Begitupun juga siswa harus bisa mengontrol diri, menahan amarah. Sebab tidak sedikit pula media yang memberitakan kasus kekerasan yang dilakukan oleh siswa terhadap gurunya, bahkan kebanyakan orang tua siswa tersebut bukan mengakui kesalahan anaknya, tetapi malah melaporkan balik guru tersebut kepada 
pihak yang berwajib. Hal tersebut terjadi karena ketidakmampuan untuk mengendalikan diri dan menahan amarah.

Setiap lembaga pendidikan pasti memiliki tujuan yang berorientasi pada hal-hal yang bersifat baik. Tidak mungkin ada lembaga pendidikan yang memiliki tujuan agar siswanya menjadi penjahat, koruptor, dan lain sebagainya. Maka tidak ada salahnya ketika siswa melakukan kesalahan, guru memberikan teguran atau sanksi agar siswa tersebut tidak mengulanginya kembali. Sebaliknya, guru bisa memberikan hadiah atau penghargaan kepada siswa yang berbuat baik atau berprestasi agar menjadi pendorong atau motivasi untuk siswa tersebut agar bisa lebih baik lagi dan juga untuk siswa yang lain agar bisa menyamai prestasi yang diraih oeleh siswa tadi. Guru wajib menanamkan nilai-nilai kebaikan kepada siswanya seperti tolong menolong, simpati, empati dan lain sebagainya. Sebab, hakikatnya tugas guru bukanlah hanya sekedar trasfer ilmu kepada siswa, akan tetapi yang lebih penting dari itu adalah menjadikan siswa memiliki akhlak dan perilaku yang baik sesuai dengan misi diutusnya Rasulullah Saw.

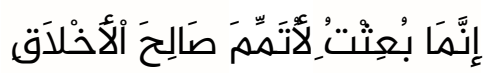

"Sesungguhnya aku diutus untuk menyempurnakan akhlak yang baik." (HR Bukhari)

\section{SIMPULAN}

Berdasarkan pemaparan dan analisa data yang telah diuraikan pada bab sebelumnya, maka diperoleh kesimpulan sebagai jawaban dari rumusan masalah sebagai berikut:

1. Isi kandungan dari surat Ali Imran ayat 134 adalah menjelaskan tentang sifat yang dimiliki oleh orang yang bertakwa. Dalam ayat tersebut disebutkan empat sifat yang dimiliki oleh orang yang bertakawa diantaranya adalah suka berinfaq, mampu menahan amarah, memafkan orang lain, dan berbuat baik.

2. Sifat-sifat yang dimiliki oleh orang bertakwa berdasarkan al-Qur'an surat Ali Imran ayat 134 juga bisa dikategorikan kedalam nilai-nilai pendidikan sosial yang berlaku dalam kehidupan bermasyarakat. Sebab keempat sifat tersebut tidak bisa diamalkan tanpa adanya interaksi antara satu dengan yang lainnya. Ibnu Katsir menjelaskan: Pertama, orang yang selalu berinfak baik dalam keadaan lapang maupun sempit, susah maupun senang, sakit maupun sehat. Kedua, orang yang mampu menahan amarah padahal dia sendiri mampu melampiaskannya, maka berdasarkan hadis Rasul orang tersebut merupakan orang yang kuat. Ketiga, orang yang memaafkan orang yang telah berbuat aniaya terhadap dirinya meskipun tanpa dimintainya, sehingga tiada suatu uneg-uneg pun yang ada dalam hati mereka terhadap seseorang. Hal ini merupakan 
BESTARI

Vol. 17, No. 1, 2020

p-ISSN 1907-1337; e-ISSN 2807-6532

akhlak yang paling sempurna. Keempat, orang yang berbuat baik, sebab perbuatan baik akan melahirkan kecintaan Allah juga disukai sesama manusia.

3. Nilai-nilai pendidikan sosial yang terdapat dalam al-Qur'an surat Ali Imran ayat 134 jika dihubungkan dengan pendidikan masa kini sangatlah relevan, mengingat akan pentingnya nilai-nilai tersebut untuk dimiliki oleh pendidik maupun peserta didik dan masyarakat pada umumnya. Sebab dizaman sekarang ini, rasa peduli, tolong menolong, simpati dan empati terhadap orang lain sudah mulai perlahan hilang. Sehingga menjadi hal yang wajib bagi guru untuk memberikan pengajaran dan bimbingan kepada siswa agar memiliki kepekaan sosial.

\section{DAFTAR PUSTAKA}

Atmajaya, R. (2010). Menjadi Pemenang Saat Diuji Allah. Jakarta: Qultum Media.

Chami, N. (2006). Konsep Zakat Dalam Islam dan Implikasinya Terhadap Pendidikan Sosial. In Skripsi. Semarang: IAIN Walisongo.

Damsar, \& Indrayani. (2016). Pengantar Sosiologi Pedesaan. Jakarta: Kencana.

Darmadi, H. (2019). Pengantar Pendidikan Era Globalisasi: Konsep Dasar, Teori, Strategi dan Implementasi dalam Pendidikan Globalisasi. Jakarta: Animage.

El-Jambey, Z. A. (2016). Mengetuk Nurani, Membuka Hati. Jakarta: PT. Elex Media Komputindo.

Fadhilah, N. (2016). Nilai-Nilai Pendidikan Sosial Dalam Tradisi Sedekah Kematian Di Dusun Pekodokan Desa Wlahar Kecamatan Wangon Banyumas. In Skripsi. Purwokerto: IAIN Purwokerto.

Hasan, A. S. (2018). Mendulang Angin. Banda Aceh: Syiah Kuala University Press.

Helaluddin, \& Wijaya, H. (2019). Analisis Data Kualitatif: Sebuah Tinjauan Teori dan Praktik. Makkasar: Sekolah Tinggi Theologia Jaffray.

Huda, N., \& Dkk. (2017). Ekonomi Pembangunan Islam. Jakarta: Kencana.

Iqbal, M. (2005). Ramadan dan Pengendalian Diri. Jakarta: Penerbit Erlangga.

Moleong, L. J. (2010). Metode Penelitian Kualitatif. Bandung: Remaja Rosda Karya.

Monib, M., \& Bahrawi, I. (2011). Islam Dan Hak Asasi Manusia Dalam Pandangan Nurcholish Madjid. Jakarta: PT. Gramedia Pustaka Utama.

Muallifah. (2008). Konsep Pendidikan Integral Dalam Surat Al-Alaq Ayat 1-5. In Skripsi (Vol. 5). Yogyakarta: UIN Sunan Kalijaga. 
Muhsin. (2004). Bertetangga Dan Bermasyarakat Dalam Islam. Jakarta: Al-Qalam.

Munasifah. (2004). In Skripsi. Semarang: IAIN Walisongo.

Parmono, W. H., \& Ismunandar. (2017). 17 Tuntunan Hidup Muslim. Yogyakarta: Deepublish.

Purwanti, L. D. (2016). Nilai-Nilai Pendidikan Sosial Dalam Novel Tenggelamnya Kapal Van Der Wijck Karya Buya Hamka. In Skripsi. Salatiga: IAIN Salatiga.

Sanusi, U., \& Suryadi, R. A. (2018). Ilmu Pendidikan Islam. Sleman: Deepublish.

Sholihat, A. L. (2019). Nilai-Nilai Pendidikan Islam Yang Terkandung Dalam Al-Qur'an Surah Luqman Ayat 12-15 Perspektif Tafsir AlMishbah Serta Implikasinya Dalam Kehidupan. In Skripsi. Serang: UIN Sultan Maulana Hasanuddin.

Supiana. (2017). Metodologi Studi Islam. Bandung: PT Remaja Rosdakarya.

Syahrul. (2016). Indahnya Hidup Bersama Allah. Jakarta: PT. Elex Media Komputindo.

Syukur, Y., \& Nahar, M. (2014). Kekuatan Memaafkan. Jakarta: PT Bhuana Ilmu Populer.

Tirtarahardja, U., \& La Sulo, S. . (2008). Pengantar Pendidikan. Jakarta: PT Asdi Mahasatya. 